Key Words:

Corrosion

Heavy water

Storage drums

Retention:

\#Permanent\#

\title{
DEGRADATION EVALUATION OF HEAVY WATER DRUMS AND TANKS
}

\author{
J. I. Mickalonis \\ P. R. Vormelker
}

JULY 2009

Savannah River National Laboratory

Savannah River Nuclear Solutions

Aiken, SC 29808

Prepared for the U.S. Department of Energy Under

Contract Number DE-AC09-08SR22470

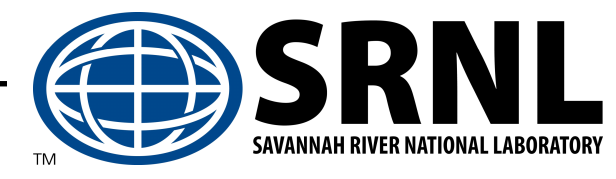




\section{DISCLAIMER}

This work was prepared under an agreement with and funded by the U.S. Government. Neither the U. S. Government or its employees, nor any of its contractors, subcontractors or their employees, makes any express or implied:

1. warranty or assumes any legal liability for the accuracy, completeness, or for the use or results of such use of any information, product, or process disclosed; or

2. representation that such use or results of such use would not infringe privately owned rights; or

3. endorsement or recommendation of any specifically identified commercial product, process, or service.

Any views and opinions of authors expressed in this work do not necessarily state or reflect those of the United States Government, or its contractors, or subcontractors.

Printed in the United States of America

Prepared for

U.S. Department of Energy 


\section{TABLE OF CONTENTS}

LIST OF FIGURES .....................................................................................................

LIST OF TABLES............................................................................................................................iv

LIST OF ACRONYMS ....................................................................................................................

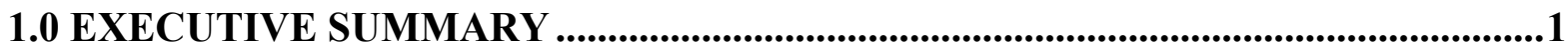

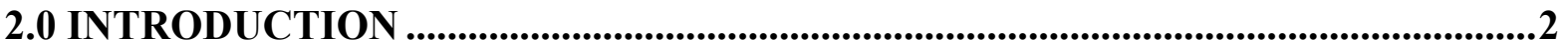

3.0 FABRICATION CODES AND STANDARDS .........................................................2

3.1 Heavy Water Drums ..................................................................................................2

3.2 Heavy Water Tanks .........................................................................................................3

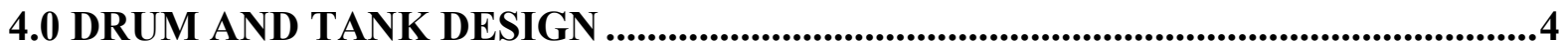

4.1 Drum Dimensions and Characteristics ..............................................................................4

4.2 Tank Dimensions and Description.........................................................................................5

5.0 HEAVY WATER CHARACTERIZATION .....................................................................6

6.0 SERVICE HISTORY ............................................................................................................

6.1 Drum Failures............................................................................................................................

6.2 Changes in Weld Design and Welding Procedures..........................................................10

6.3 Drum Handling, Storage and Inspections....................................................................11

6.4 Testing ..................................................................................................................................12

6.4.1 Drum Testing Post Fabrication ........................................................................................12

6.4.2 Drum Testing During Service...........................................................................................13

6.4.3 Laboratory Testing In Support of Drums ...................................................................13

6.4.4 Testing of Tanks...............................................................................................................14

6.4.5 NDE Testing For Drums and Tanks ..............................................................................14

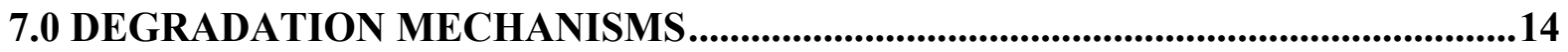

7.1 Crevice Corrosion ...............................................................................................................15

7.2 Pitting Corrosion ....................................................................................................................16

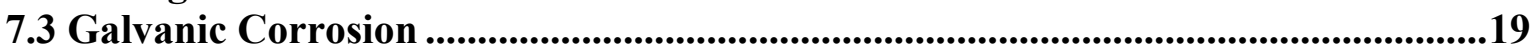

7.4 Microbiological Corrosion.................................................................................20

7.5 Stress Corrosion Cracking .........................................................................................21

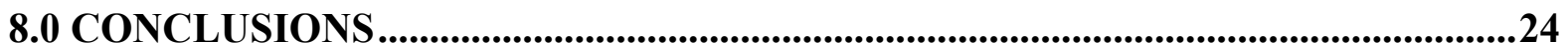

9.0 REFERENCES ..................................................................................................................25

APPENDIX A. Heavy Water Drum Failures Listing.............................................................29 


\section{LIST OF FIGURES}

4-1 Heavy Water 5B Shipping Drum (note detail of crevice closing weld ..........................5

6-1 Metallographic cross section of a pit in drum corroded during outside exposure..........8

6-2 Fly ash pit morphology on drum failure in early 1990's ............................................9

6-3 Cracking associated with external pitting of drum ....................................................

6-4 Crevice corrosion in bottom to side wall weld ..........................................................

6-5 Schematic drawing of curl weld closure for heavy water storage drum ....................10

6-6 New design for attachment of bottom to the sidewall of heavy water storage drums.11

7-1 Probability of crevice corrosion initiation as a function bold/crevice area ratio ........16

7-2 Effects of chloride concentration and temperature on the pitting potential of 304 stainless steel

7-3 Pitting of nickel containing alloys as a function of chloride concentration and $\mathrm{pH}$ values in air saturated solutions at $60^{\circ} \mathrm{C}$

7-4 Pitting of stainless steels in chloride-containing and thiosulfate containing solutions at 24-hour potentiostatic tests

7-5 Effect of chloride concentration on the SCC susceptibility of 304 stainless steel exposed at $100{ }^{\circ} \mathrm{C}$ under the concentrating condition of the Wick tests

7-6 Effect of temperature, $\mathrm{pH}$ and chloride concentration on SCC susceptibility of 304 stainless steel in sodium chloride solutions

\section{LIST OF TABLES}

3-1 Codes and Standards for Drum Fabrication of UN1A1 Drums.....................................3

3-2 Codes and Standards for Drum Fabrication of DOT 5C Drums ...................................3

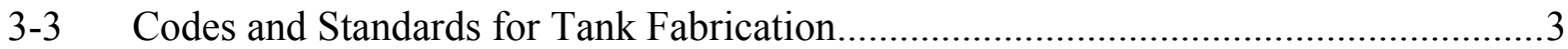

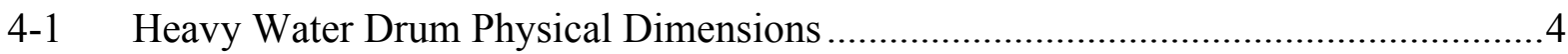

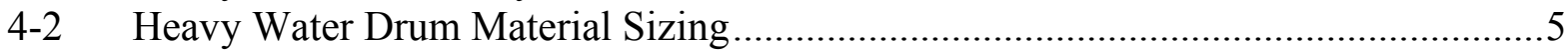

4-3 Heavy Water Tank Dimensions.............................................................................

5-1 Parametric Ranges for Characterization of Heavy Water Inventory .............................6 


\section{LIST OF ACRONYMS}

$\begin{array}{ll}\text { ASME } & \text { American Society of Mechanical Engineers } \\ \text { ASNT } & \text { American Society of Nondestructive Testing } \\ \text { ASTM } & \text { American Society for Testing and Materials } \\ \text { BPVC } & \text { Boiler and Pressure Vessel Code } \\ \text { CFR } & \text { Code of Federal Regulations } \\ \text { DOT } & \text { Department of Transportation } \\ \text { IAEA } & \text { International Atomic Energy Agency } \\ \text { MIC } & \text { Microbiological Influenced Corrosion } \\ \text { NDE } & \text { Non-Destructive Examination } \\ \text { Ppm } & \text { parts per million } \\ \text { SCC } & \text { Stress Corrosion Cracking } \\ \text { SFP } & \text { Spent Fuel Project } \\ \text { SRS } & \text { Savannah River Site } \\ \text { tpi } & \text { threads per inch } \\ \mu S & \text { micro-Siemens } \\ 304 & \text { Type 304 stainless steel }\end{array}$




\subsection{EXECUTIVE SUMMARY}

Heavy water with varying chemistries is currently being stored in over 6700 drums in L- and Kareas and in seven tanks in L-, $\mathrm{K}$-, and $\mathrm{C}$-areas. A detailed evaluation of the potential degradation of the drums and tanks, specific to their design and service conditions, has been performed to support the demonstration of their integrity throughout the desired storage period. The 55-gallon drums are of several designs with Type 304 stainless steel as the material of construction. The tanks have capacities ranging from 8000 to 45600 gallons and are made of Type 304 stainless steel. The drums and tanks were designed and fabricated to national regulations, codes and standards per procurement specifications for the Savannah River Site.

The drums have had approximately 25 leakage failures over their $50+$ years of use with the last drum failure occurring in 2003. The tanks have experienced no leaks to date. The failures in the drums have occurred principally near the bottom weld, which attaches the bottom to the drum sidewall. Failures have occurred by pitting, crevice and stress corrosion cracking and are attributable, in part, to the presence of chloride ions in the heavy water.

Probable degradation mechanisms for the continued storage of heavy water were evaluated that could lead to future failures in the drum or tanks. This evaluation will be used to support establishment of an inspection plan which will include susceptible locations, methods, and frequencies for the drums and tanks to avoid future leakage failures. 


\subsection{INTRODUCTION}

Heavy water or moderator is currently stored in stainless steel storage drums and large stainless steel cylindrical tanks, which are housed inside L-, K- and C-area buildings at the Savannah River Site (SRS). The heavy water, which was used in the SRS reactors, contains various levels of tritium and other impurities.

The drums and tanks provide a leak tight barrier to the environment for continued storage of heavy water, while the drums also provide a transportation package. Changes in the drum and tank physical conditions and properties, and any subsequent affect on leak tightness and structural stability need to be evaluated to assure extended service. The primary changes of concern are those resulting from corrosion.

Life management elements that are being applied to the drums and tanks to support continued service throughout the desired service life include: degradation evaluations, in-service inspections, and leak detection. This report provides a detailed evaluation of the degradation mechanisms that the tanks and drums are subjected to for heavy water storage at SRS. The results will be input to an in-service inspection plan. This evaluation includes a review of the service-induced degradation mechanisms for stainless steel based on an established material condition at present, service history of the drums and tanks, previous nondestructive examinations (NDE) and testing, and literature data.

\subsection{FABRICATION CODES AND STANDARDS}

The heavy water drums and tanks were designed and fabricated to national regulations, codes and standards. These codes and standards are listed in Section 3.1 for drums and Section 3.2 for tanks.

\subsection{HEAVY WATER DRUMS}

The most recent procurement specification for heavy water drums referenced several national codes, standards and regulations, which are shown in Table 3-1 [1, 2]. The 2000 drums that were procured in 1995 were made according to this specification. These drums are classified as UN 1A1-X1 per Title 49, Part 178, subpart L of the Code of Federal Regulations (CFR).

Table 3-1 Codes and Standards for Drum Fabrication of UN1A1 Drums

\begin{tabular}{|l|l|}
\hline \multicolumn{1}{|c|}{ Code/Standard } & \multicolumn{1}{c|}{ Purpose } \\
\hline 49 CFR, 178 Subpart L & Fabrication \\
\hline 49 CFR, 178 Subpart M & Testing \\
\hline ASTM A240-94 & Material - sheet \\
\hline ASTM A312-94 & Material - piping \\
\hline ASTM A380-88 & Cleaning \\
\hline ASME BPVC & Welding and Inspection \\
\hline ASNT SNT-TC-1A & Inspection \\
\hline
\end{tabular}


Another drum classification, DOT 5C, were procured to a specification with a different set of codes and standards [3]. The DOT requirements were those designated in the CFR. The known codes and standards for 5C drums are shown in Table 3-2. Fabrication to different codes and standards did not change significantly the physical characteristics of the drums as discussed in Section 4.1.

Table 3-2 Codes and Standards for Drum Fabrication of DOT 5C Drums

\begin{tabular}{|l|l|}
\hline \multicolumn{1}{|c|}{ Code/Standard } & \multicolumn{1}{c|}{ Purpose } \\
\hline 49CFR, 178.83 & Fabrication and testing \\
\hline ASME SA240 & Material - sheet \\
\hline ASTM A380-88 & Cleaning \\
\hline ASME BPVC & Welding, Inspection and Labeling \\
\hline ASNT SNT-TC-1A & Inspection \\
\hline
\end{tabular}

According to the earliest known procurement specification, drums were procured as DOT 5B. These drums make up the most significant percentage of the current drum inventory. No additional standards, codes or regulations are specifically listed in this specification [4]. Several procurement specifications have been used throughout the history of the drums. Drum procurements are known to have occurred in 1956, 1967, 1969, 1970, 1979, and 1995.

A lot of 2000 drums procured starting in 1995 had changes in drum design and the addition of digital radiography for inspecting all the drums, which is discussed in further detail in Sections 6.1 and $6.2[1,2]$. Digital radiography was added during receipt inspection to verify the quality of the upper and lower circumferential weld. These inspections were performed in accordance with Section V of the ASME BPVC and a methodology developed at SRS.

\subsection{HEAVY WATER TANKS}

The stainless steel tanks were designed and fabricated in accordance with several editions of the ASME code for Unfired Vessels. These different editions are shown in Table 3-3 for each tank configuration as a function of their capacity and tank number. These standards were taken from the tank drawings. These tanks were placed in service and have not leaked since construction.

Table 3-3 Codes and Standards for Tank Fabrication

\begin{tabular}{|l|l|l|}
\hline Tank Number & Capacity (gal) & Fabrication Code \\
\hline $\begin{array}{l}205.2 \mathrm{~K} \\
205.2 \mathrm{~L}\end{array}$ & 8,000 & $\begin{array}{l}\text { ASME, Sec VIII, Par. LW31 } \\
\text { to U38, 1952 }\end{array}$ \\
\hline $204-\mathrm{L}, 204-\mathrm{K}$ & 12,760 & ASME U-68, 1949 \\
\hline $205-\mathrm{L}, 205-\mathrm{K}$ & 38,000 & ASME U-68, 1949 \\
\hline $205-\mathrm{C}$ & 45,600 & ASME U-68, 1949 \\
\hline
\end{tabular}


SRNL-TR-2009-00195, REVISION 0

\subsection{DRUM AND TANK DESIGN}

This section discusses the physical dimensions, materials of construction, and attributes of the drums in Section 4.1 and the tanks in Section 4.2.

\subsection{DRUM DIMENSIONS AND CHARACTERISTICS}

The heavy water drums were fabricated per DOT 5B, 5C or UN1A1 standards depending on when they were procured. The materials of construction initially were either aluminum or Type 304 stainless steel (304). The drums presently in service are 304 only so this report focuses on the service history and degradation mechanisms for 304. For only the last drum procurement, the specification called for material made to ASTM A240, which is a specification for 304 but has compositional ranges that include Type 304L stainless steel. Since certified material reports are not available, these drums may be either 304 or 304L. The ' $\mathrm{L}$ ' designation denotes a lowcarbon grade of stainless steel, which is more corrosion resistant. Through the remainder of this report, 304 will be used as inclusive of $304 \mathrm{~L}$. In the discussion of corrosion mechanisms the focus will be on 304 since it is less corrosion resistant.

The sizes of these drums are similar and are summarized in Table 4-1, although the capacity of the drums has decreased slightly. The outer diameter is measured at the robars or rolling hoops of the drums. Tolerances for the height and diameter were \pm 0.125 in and \pm 0.0625 in, respectively. The outside diameter tolerance for the type $1 \mathrm{~A} 1$ drums was increased to $\pm 0.125 \mathrm{in}$.

The drum heads must be convex with minimum and maximum dimensions as shown in Table 4-1. Concave heads are not necessarily detrimental to drum viability. Two drums that were used for Hot Sump operations with P reactor developed concave heads having a deflection from 1.75 to 2.5 in [5]. A stress analysis at the time showed that the resulting strain (6.5-17\%) was well below the failure strain of $40 \%$ for mildly cold worked 304 [6].

Table 4-1 Heavy Water Drum Physical Dimensions

\begin{tabular}{|c|c|c|c|c|c|c|c|}
\hline \multirow{2}{*}{$\begin{array}{c}\text { Drum } \\
\text { Type }\end{array}$} & \multicolumn{3}{|c|}{ Dimensions (in) } & \multicolumn{2}{c|}{ Capacity (US gal) } & \multicolumn{2}{c|}{ Head Convexity (in) } \\
\cline { 2 - 8 } & ID & OD & Total Height & Max & Min & Max & Min \\
\hline 5B & 22.5 & 23.75 & 35.125 & 57.75 & 57.2 & 0.875 & 0.625 \\
\hline 5C & 22.5 & 24.688 & 34.75 & 56.6 & 56.1 & 0.875 & 0.625 \\
\hline 1A1 & 22.5 & 24.688 & 34.375 & 55.25 & 55.62 & 0.375 & 0.25 \\
\hline
\end{tabular}

Each drum has two openings in the top, 0.75 in and 2.00 in, which for all the drums are the same dimensions. The openings are located diametrically opposite one another. These openings have fittings or closures that must prevent leaking, which is determined by the threads per inch (tpi). All the drums have chimes on the top and bottom which prevent these sections from contacting surfaces.

A drawing of a 5B drum is show in Figure 4-1 and the sizing requirements for each drum type are shown in Table 4-2. 


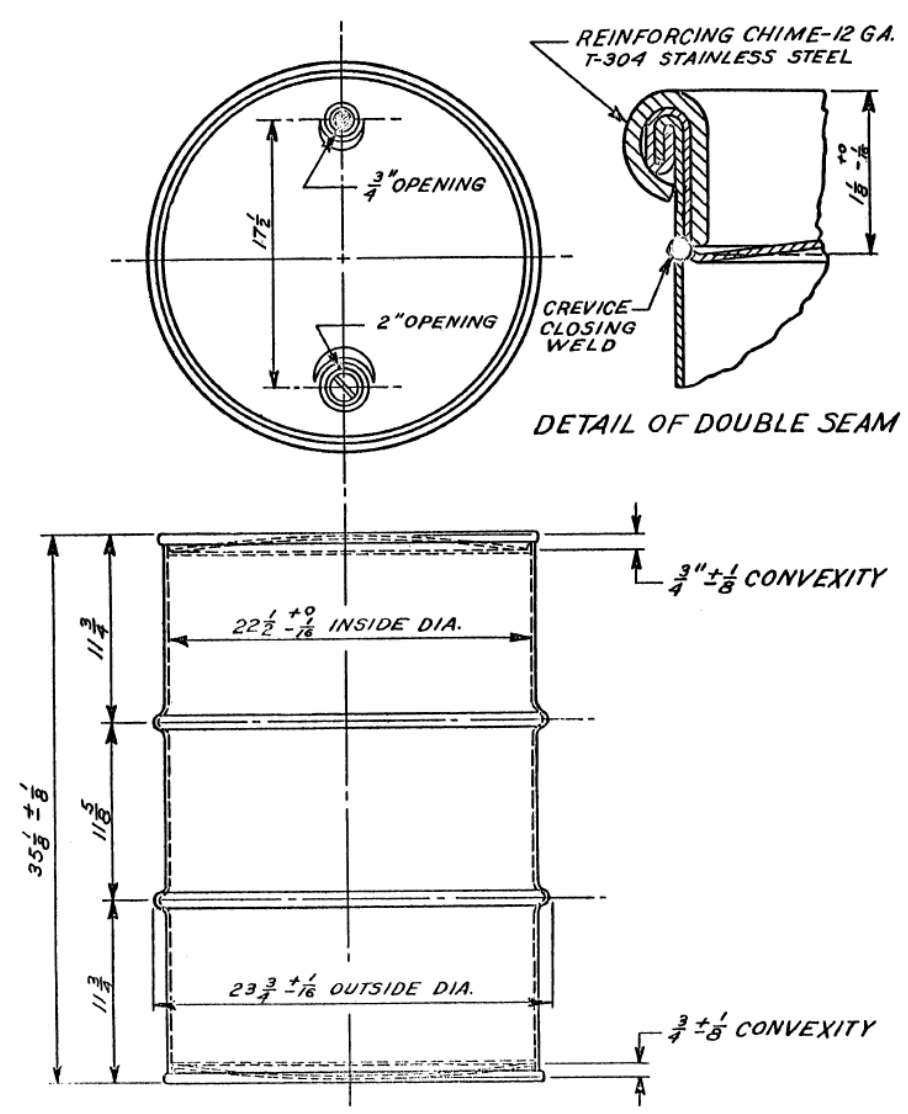

Figure 4-1 Heavy Water 5B Shipping Drum (note detail of crevice closing weld

Table 4-2 Heavy Water Drum Material Sizing

\begin{tabular}{|c|c|c|c|c|c|}
\hline Drum Type & Body (gage) & Heads (gage) & Chimes (gage) & Robars & Fittings*** \\
\hline 5B & 16 & 16 & 12 & NS** & 2 and 0.75 in \\
\hline 5C & 16 & 0.0533 in* & 12 & Sch 40 & $\begin{array}{c}2 \text { in, } 11.5 \text { tpi } \\
0.75 \text { in, } 14 \text { tpi }\end{array}$ \\
\hline 1A1 & 14 or 16 & 14 or 16 gage & 14 or 16 & 0.75 "sch 40 & $\begin{array}{c}2 \text { in, } 11.5 \text { tpi } \\
0.75 \text { in, } 14 \text { tpi }\end{array}$ \\
\hline
\end{tabular}

* A minimum thickness was specified.

** A specification for size or material was not given.

*** For $1 \mathrm{~A} 1$, materials of construction can be $304,304 \mathrm{~L}$ or $316 \mathrm{~L}$ stainless steels.

\subsection{TANK DIMENSIONS AND DESCRIPTION}

All the tanks are cylindrically shaped with the long axis oriented horizontally. The tanks sit in concrete saddles with wear plates protecting the primary containment boundary. The tanks are fabricated of 304 with a 0.08 max carbon concentration. The tanks have dished ends with radii of curvature of 9'6" and 11'0" for the 8000 gallon tank and the larger three sizes, respectively. Overall tank dimensions are given in Table 4-3. The tanks have flanged openings of varying sizes; the number of openings differs for each tank. Each tank also has a manhole, which has a 
carbon steel manhole cover. All characteristics for the tanks were taken from the tank drawings [7-10].

Table 4-3 Heavy Water Tank Dimensions

\begin{tabular}{|c|c|c|c|}
\hline Tank Capacity (gallon) & $\begin{array}{c}\text { Outside Diameter } \\
\text { (feet) }\end{array}$ & $\begin{array}{c}\text { Length } \\
\text { (feet) }\end{array}$ & $\begin{array}{c}\text { Plate thickness } \\
\text { (inch) }\end{array}$ \\
\hline 8000 & 10 & 12 & 0.375 \\
\hline 12760 & 12 & 12.7 & 0.5 \\
\hline 38000 & 12 & 43 & 0.5 \\
\hline 45600 & 12 & 52 & 0.5 \\
\hline
\end{tabular}

\subsection{HEAVY WATER CHARACTERIZATION}

The water quality of the heavy water in the drums and tanks has been well characterized [11-13]. The water quality parameters that may have some effect on the corrosion of the drums and tanks are conductivity, $\mathrm{pH}$, turbidity and the concentrations of chloride, mercury, copper and potassium permanganate. Besides $\mathrm{pH}$, the higher these parameters are the more likely corrosion will occur. The values are shown in Table 5-1 along with their measured high and low values for both the drums and the tanks. The lowest non-zero values are given.

The chemistries of the heavy water in the tanks have fewer impurities and significantly lower conductivities and turbidity and a tighter $\mathrm{pH}$ range. The last chemical analyses available were from 1996, so the tanks should be analyzed again. The water cleanliness should provide the tanks with a less corrosive environment and thereby a longer life, which is manifested by the occurrence of no leaks to date.

Table 5-1 Parametric Ranges for Characterization of Heavy Water Inventory

\begin{tabular}{|l|c|c|c|c|}
\hline & \multicolumn{2}{|c|}{ Drums } & \multicolumn{2}{c|}{ Tanks* } \\
\hline \multicolumn{1}{|c|}{ Parameter (units) } & High & Low & High & Low \\
\hline Conductivity $(\mu \mathrm{s} / \mathrm{cm})$ & 86700 & 0.1 & 4.3 & 0.73 \\
\hline Chloride $(\mathrm{ppm}) * *$ & $>99.9$ & 0.1 & $<0.1$ & 0.03 \\
\hline Mercury $(\mathrm{ppm})$ & 0.233 & 0.001 & & $<0.002$ \\
\hline Copper $(\mathrm{ppm})$ & 0.93 & 0.01 & & $<0.05$ \\
\hline $\mathrm{KMnO}_{4}(\mathrm{mg} / \mathrm{ml})$ & 666 & 0.1 & $9.9 \mathrm{E}-5$ & $3.4 \mathrm{E}-5$ \\
\hline pH & 12.82 & 0.74 & 6.5 & 4.9 \\
\hline Turbidity $(\mathrm{NTU})$ & 4650 & 1 & 1.2 & $<0.5$ \\
\hline
\end{tabular}

* Data from tanks in L-area not available for chloride, mercury, potassium permanganate, etc

** On the drum ticket 99.9 was the highest that could be recorded in the available space. The actual results might be higher.

The percentage of the water that is $\mathrm{D}_{2} \mathrm{O}$ varies for the drums from 0.04 to $99.97 \mathrm{~mol} \%$ with twothirds of the drums having greater than $50 \mathrm{~mol} \% \mathrm{D}_{2} \mathrm{O}$. The tanks contain mostly heavy water with greater than $98 \mathrm{~mol} \% \mathrm{D}_{2} \mathrm{O}$. Additional concentrations that are characterized include silver, 
SRNL-TR-2009-00195, REVISION 0

gold, gadolinium, tritium, and the lanthanides. These constituents will not affect the corrosion of the drums or tanks.

\subsection{SERVICE HISTORY}

Heavy water has been stored in stainless steel and aluminum drums without significant leakage since 1952. The tanks used to store heavy water since the 1950 s have experienced no known leaks to date. Drum failures have occurred due to both corrosion and welding defects. Changes in weld design and welding procedure have been enacted in attempts to minimize these failures at the source. Improvements to handling, storage and inspection have been used to remove additional sources of corrosion initiation as well as means of verifying the drum condition. Testing has also been conducted for new drums as specified in procurement specifications and when a used drum is brought into service. Some additional testing has been conducted to demonstrate the integrity of the drums.

Most of the drums currently in the inventory were procured prior to 1990, except for one lot of 2000 drums, which was procured in 1995-6. The drums remaining in service are made of 304.

\subsection{DRUM FAILURES}

Drum failures have occurred throughout the history of heavy water storage although these failures have not had major consequences. On average a failure of leakage has occurred every two years, although the last failure was more than five years ago. The welds at the drum chimes have been the source of failures back to 1956 when the first noted drum design change occurred [14]. A seal weld was included to eliminate a crevice. Metallurgical evaluation of six new drums in 1967, which had failed a leak test, showed weld defects as the cause [15]. Another drum design change moved the end girth welds $3 / 16$ " towards the drum center to minimize the crevice formed between the ends and sidewall. Between 1970 and 1973, six more drum failures occurred with three from weld defects and the other three from pitting corrosion. All six had at one time contained heavy water classified as degraded, although the chemistries for this degraded water were not known. The weld defects were classified as shrinkage cracks, lack of penetration and excess burn-through during fabrication.

Up to 1975 , only 12 stainless steel drum failures had occurred in over 10,000 handled, which resulted from mechanical defects or pitting caused by storage of a corrosive medium [14]. In 1975, pitting originating from the exterior surface started to occur. These pits were associated with fly ash deposits that occurred while the drums were stored outside. Outside storage was used for unfilled drums, which were positioned with their bottoms up to protect the bung threads. The pit morphology is shown in Figure 6-1. This morphology is typical for those associated with microbiological corrosion (MIC), i.e. the internal pitting is more extensive that what the external view indicates.

In 1982 another drum failure occurred at the bottom to sidewall weld only three months after filling [16]. The drum contained heavy water with greater than $100 \mathrm{ppm}$ chloride. The specific weld defect was not identified but was probably a crevice since the welds showed significant corrosion. 


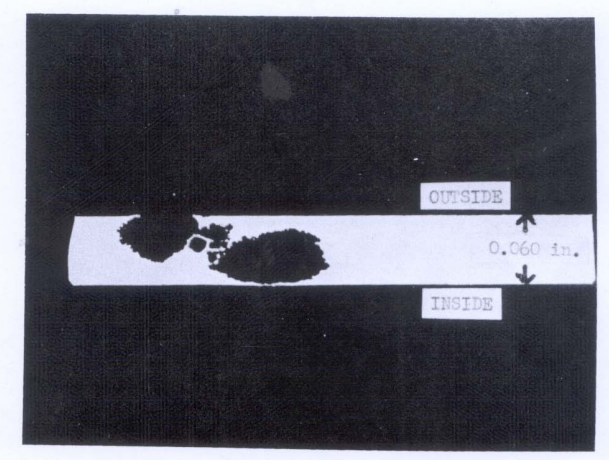

Figure 6-1 Metallographic cross section of a pit in drum corroded during outside exposure [14]

In the late 1980's, a drum failed which was found to have chime bands that were suspected to be carbon steel because of the magnetic properties [17]. This drum was from a group of drums (serial numbers 2000-5499) that were received on site around 1960. The observable corrosion was primarily on the chimes and believed to be from atmospheric corrosion from outside storage. The actual cause of the failure was unknown but not believed to be associated with the galvanic couple between a carbon steel chime and the stainless steel drum. In this electrochemical couple, carbon steel is the anode and corrodes preferentially to stainless steel, although corrosion products can lead to stainless steel corrosion. Similar observation of a number of rusted carbon steel chimes was observed on drums currently stored in 105-L. These drums were believed to have been stored either outside or in high moisture environments. In their current inside storage location, galvanic corrosion (from carbon steel chimes or reinforcing rings) on the drum exterior is not expected to occur so long as moisture levels remain low.

From late 1989 to 1993, five additional failures occurred due to corrosion including stress cracking, internal and external pitting, and crevice corrosion $[18,19]$. The external pitting was attributed to sulfides which leached from fly ash that settled on empty drums stored outdoors. The corrosion morphology differs from that previously observed; compare Figure 6-2 to Figure 6-1.

Cracking was also associated with some of this pitting as shown in Figure 6-3. Crevice corrosion was the cause of one failure at the bottom weld as shown in Figure 6-4.

The most recent failure occurred in 2003 in a drum which had previously stored waste water [21]. Although the drums are cleaned, the crevice that is formed at the bottom to sidewall weld may retain some of the initial impure water. This problem was noted as far back as 1967.

Analysis of solids and liquids from the leak residue showed the presence of sodium chloride as well as a complex zinc-chloride-sulfate-hydroxide-hydrate. This particular drum had galvanized chimes. The drum was not inspected on the interior so the actual failure mechanism is unknown. 


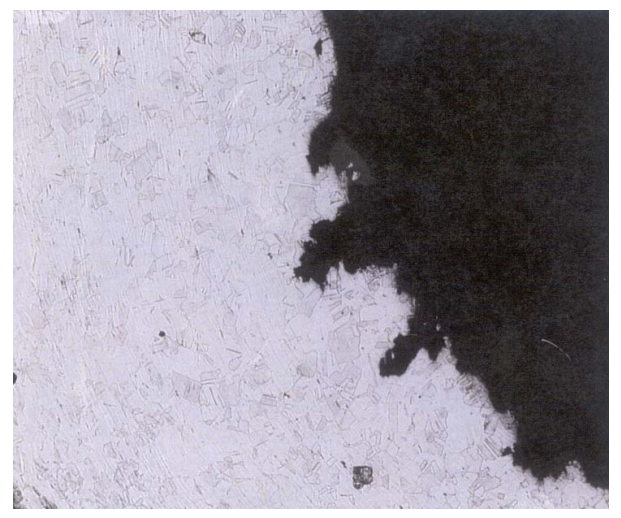

Figure 6-2 Fly ash pit morphology on drum failure in early 1990’s [20]

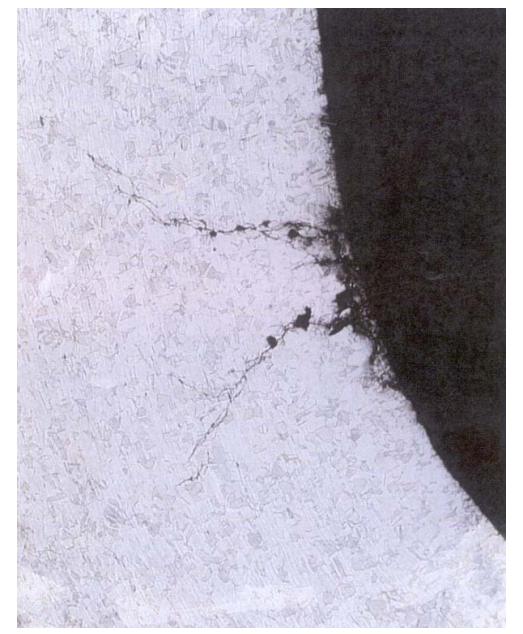

Figure 6-3 Cracking associated with external pitting of drum [20]

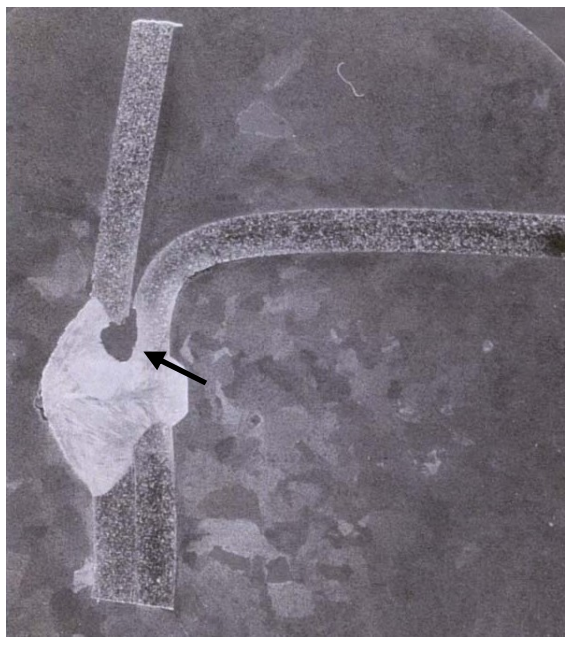

Figure 6-4 Crevice corrosion in bottom to side wall weld - arrow indicates corroding crevice $[20,23]$ 
Failures have also occurred in drums during testing after fabrication. These failures are clearly associated with poor weld quality during fabrication. Two known cases occurred in 1987 (5C) and 1995 (1A1). The first case occurred during a drop test by cracking through the heat affected zone of the top weld [22]. This weld was repaired by grinding out the crack and welding, which was found to be acceptable through dye penetrant testing. The other failure occurred with drums having a separate bottom to side wall weld and chime weld [23]. This failure was due to a welding flaw, probably lack of fusion at the T-junction between the sidewall seam weld and the top to sidewall weld. A repair of the weld was attempted but was unsuccessful which provided a leak path. Further details are discussed in Section 6.2.

A complete listing of all the drum failures is given in Appendix A

\subsection{CHANGES IN WELD DESIGN AND WELDING PROCEDURE}

The seal weld of the sidewall to the bottom or top has been changed throughout the history of drum storage so as to minimize the crevice formed at this junction. As noted above, this first change occurred in 1956 when the seal weld was included as part of the design [14]. The actual location and quality of this weld impacts the size of the residual crevice. Weld quality itself has also been an issue with numerous failures resulting in lack of fusion, porosity, and shrinkage cracks $[15,16,22,23]$.

Around 1967, the seal welds for the top and bottom were moved towards the middle (approximately 0.2") of the drum as a means to accomplish an even smaller crevice [25]. Weld quality was a noted issue at this time with several drums failing a leak test [15]. The new location of the weld produced variable sized crevices. Different drum suppliers were also evaluated with no appreciable differences in welding quality or ability to eliminate the crevice found. Sanitary drums with a single weld at the center of the drum side wall had been recommended, but whether any were procured is not known. They have not been identified during recent drum inspections or surveillances.

In 1987, failure of a weld during testing lead to a metallurgical investigation of a weld repair [22]. A recommendation resulting from that investigation required the use of a curl weld to close the open chimes as shown in Figure 6-5. This weld stopped some leaks through the bottom to sidewall weld while adding additional strengthening.

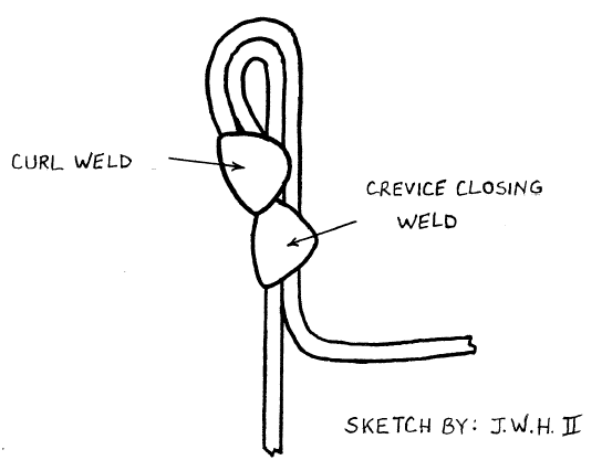

Figure 6-5 Schematic drawing of curl weld closure for heavy water storage drum [15] 
These weld quality issues have also been noted in subsequent years, especially for the procurement in 1995 of 2000 drums [23, 24]. This last shipment of drums had incurred a large number of weld defects which resulted in a $31 \%$ rejection rate. The weld defects were found through the use of digital radiography which was being performed on all the drums per the procurement specification. Changes to the welding procedure included increasing the size of the chill and purge ring to dissipate heat more efficiently, providing more purge gas, and improving the positioning of the weld torch. Rejection rate after these improvements fell to $15 \%$.

For this procurement the location of the weld had also been changed with bottom to sidewall weld being above the location of the chime as shown in Figure 6-6. The chime was attached to the bottom with a separate weld, which was made prior to the bottom to sidewall weld. This design essentially eliminates the interior crevice.

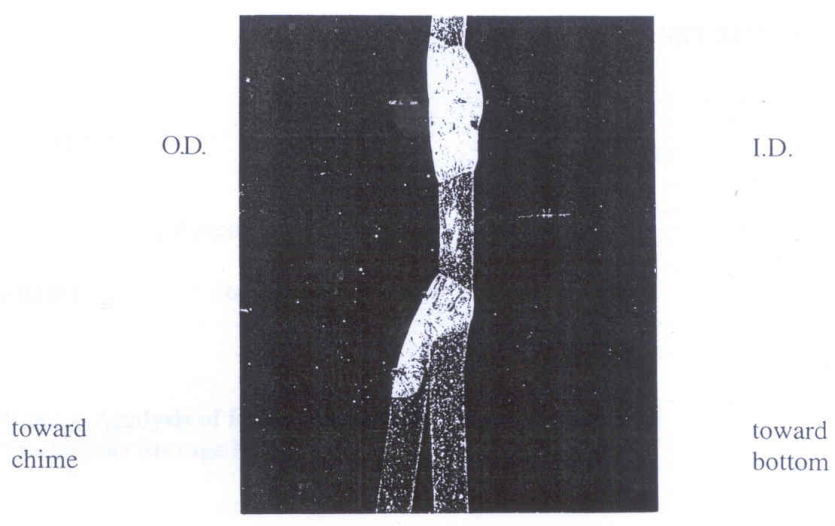

Figure 6-6 New design for attachment of bottom to the sidewall of heavy water storage drum [23]

Changes to the procurement documentation were made in 1997 and 2005 and have not been used to purchase any new drums [26-28]. Important changes that were made to the specification include changes in fabrication sequence, addition of welding inspection, and eliminated the use of digital radiography for drum inspection. A noted change in fabrication sequence was an inspection of the weld joining the drum bottom to the sidewall prior to attaching the top. This change allows the formed crevice and bottom circumferential weld to be visually inspected on the interior since this area has been the most frequent failure location. A dye penetrant test is to be performed of this area and meet ASME BPVC Section VIII requirements. In previous procurements, inspection at the vendor location of the welding process was not conducted and should lower weld defects.

\subsection{DRUM HANDLING, STORAGE AND INSPECTION}

Throughout the service history of the heavy water storage drums, improvements have been proposed for drum handling, storage and inspection to minimize the occurrence of drum failures and subsequent leakage. These changes have been implemented to varying degrees and included: 
1) Visual and nondestructive examinations (NDE) for identification of weld defects and pitting

2) Chemical analysis of heavy water for identification of corrodents

3) Addition of inhibitors

4) Use of sacrificial anodes

5) Improvement to cleaning procedure

6) Improvements to testing between uses including the addition of an air leak test

7) Inside storage

8) Use of quantitative leak detection method for leak detection during in-service (storage)

A number of these changes $(1,2,5,6$, and 7$)$ are currently being used by SFP to maintain the drums and verify drum integrity. NDE is used prior to shipment of the drums off site as discussed in Section 6.4. These inspections are point thickness measurements at several locations on drum exterior. Although quantitative leak detection is not used, SFP currently employs Kanne monitors in storage buildings to detect the presence of tritium from a leaked drum and the moderator storage areas are inspected [29].

\subsection{TESTING}

Both the tanks and the drums have been tested to demonstrate fitness for service after fabrication and between uses (for drums only). NDE thickness measurements of drum and tank sidewalls have been made and showed that for the areas investigated significant degradation had not occurred. In this section, the types of testing and known results are discussed for both the drums and tanks.

\subsubsection{Drum Testing Post Fabrication}

The drums were initially tested after fabrication per the procurement specifications to meet DOT requirements $[3,4]$. The three tests given to all drum types $(5 \mathrm{~B}, 5 \mathrm{C}, 1 \mathrm{~A} 1)$ were the air leak test, hydrostatic tests, and the drop tests. The air leak test was performed on all drums after fabrication which involved pressurizing the drum to $15 \mathrm{psig}(>4 \mathrm{psi}$ for 1A1 drums) and examining seams for leaks (by immersion for not less than 5 minutes and with the use of soaps) $[3,4,30]$.

For the $5 \mathrm{~B}$ and $5 \mathrm{C}$ drums, one drum/hundred was hydrostatic tested to 80 psig for 5 and 10 minutes, respectively; an air leak test followed the hydrostatic test. For 1A1 drums, three test drums were required by the CFR at a pressure greater than 36 psig but nominally 1.5 times the vapor pressure of heavy water at $55^{\circ} \mathrm{C}$ minus $15 \mathrm{psig}$. The time requirement was 30 minutes and no subsequent air leak test was required.

The final test was the drop test. For types $5 \mathrm{~B}$ and $5 \mathrm{C}$, one drum/hundred was filled to $98 \%$ capacity with water and dropped from 6 feet onto a concrete surface with the drum angled to hit the top chime near the large bung opening. The drum had to pass an air leak test after the drop. As discussed in Section 6.1, one drum was noted to have failed this test. For type 1A1, three drums are tested for two landing positions, diagonally on the chime and on the calculated weakest part. An air leak test is not required after the drop; if the liquid does not leak, the drum 
passes. The actual liquid used for the $1 \mathrm{~A} 1 \mathrm{drums}$ was not in the procurement specification, but the CFR provides guidance for selection of a liquid.

The 1A1 drums were also tested in a stacking test per the CFR. This test involves testing of three drums that are loaded with weight equivalent to that expected during transport. The weight is applied for 24 hours. After testing, two similar drums are stacked on the test drum for one hour. The test is passed if no leaking occurs.

\subsubsection{Drum Testing During Service}

When an empty previously used drum is to be placed back into service for heavy water storage, a visual inspection of empty drum is performed to verify it is free of deformations (bulges, large dents) or other conditions that could compromise container integrity [31]. A drum found with these characteristics is segregated and labeled not to be used. No additional testing is performed prior to return to service.

\subsubsection{Laboratory Testing In Support of Drums}

Laboratory testing in support of the drums has been conducted at three different times to assess either the integrity of used drums or the degradation of drums. The tests are discussed chronologically.

In 1978, testing was conducted to assess pit propagation in used drums that are stored inside [32]. Samples from three severely pitted drums were immersed into tap water, which was used as a simulant for heavy water. The eleven-month test was conducted at $80{ }^{\circ} \mathrm{C}$, which is higher than normal inside storage conditions. Water was added twice daily because of evaporative losses. The report was unclear as to whether the sample became fully air-exposed. No significant change was noted in the appearance of the pits. These results imply that if a heavy water with low impurities is placed in a previously used drum pits should not continue to grow during storage.

In 1992, testing was conducted on two degraded 5B drums to qualify them as Industrial Package Type 2 (IP-2) per the International Atomic Energy Agency (IAEA) requirements [33]. This testing involved a free drop from $1.2 \mathrm{~m}$ on to a horizontal unyielding surface and a stacking test with a load of 5 times the mass of the package for a period of 24 hours. A different drum was used for each test. Both drums met the testing criteria of the IAEA regulations. They had only slight dents and passed a hydrostatic (22 psig) test and an air leak (15 psig) test with water immersion for 5 minutes. Similar functionality tests were also performed prior to testing.

The final testing was conducted to assess the effect on corrosion, especially crevice corrosion, of chloride concentration, solution $\mathrm{pH}$, and temperature [34]. Electrochemical and immersion testing was conducted for up to 22 months. Additionally electrochemical impedance spectroscopy was evaluated as a monitoring technique. The results showed that both pitting and crevice corrosion increased with increases in chloride concentration and temperature and decreases in $\mathrm{pH}$. Recommended storage conditions were maximum $50 \mathrm{ppm}$ chloride, $\mathrm{pH} 5$ and room temperature. The impedance spectroscopy did not prove to be an effective monitoring tool. 
SRNL-TR-2009-00195, REVISION 0

\subsubsection{Testing of Tanks Post Fabrication}

Documentation for testing of the heavy water tanks is limited to the drawings. The drawings indicated that each tank was hydrotested at a pressure of $45 \mathrm{psi}$, which was well above the design pressure of 30 psi. Additionally, the welds were radiographed for up to 5\% of the total linear footage and at all intersections in butt welds [7-10].

\subsubsection{NDE Testing For Drums and Tanks}

Ultrasonic measurements of wall thickness have been conducted on both the drums and tanks. For the drums, these measurements are performed prior to shipment offsite and are an indication that the drums have wall thicknesses above minimum values [35]. The inspections of the tanks are part of a preventive maintenance program [37].

NDE reports from 2000 to 2008 were reviewed [36]. All drums were found to have acceptable wall thickness and no pitting indications were observed. The measurements are made at three locations on the sidewall and at one location on top of the drum. Measurements are not made along or near the bottom seal weld. The acceptance criteria per the procedure, SOP-MODS-004$\mathrm{L}$, are minimum thickness of 0.054 in and maximum thickness of 0.071 in [35].

In 2005 several drums from the L-area storage facility were examined because of visual degradation including gouges, dents, concave lids, convex lids and rust [38]. The UT thickness measurements were found to be within the acceptance criteria with no signs of interior pitting. This examination showed that exterior condition is not necessarily indicative of interior condition.

The NDE measurements on the heavy water tanks are made at 90-degree intervals around the circumference of the tanks at a number of locations along the length, which depends on the tank design. The ultrasonic measurements are made on both sides of a circumferential weld and on the head ends. Corrosion especially pitting has not been noted for the tanks. The minimum wall thickness measured was 0.491 for tanks in C- and K- areas with an initial wall thickness of 0.5 " nominally $[37,39]$. In K-area, tank \# 205.2 had an initial wall thickness of 0.375 " and measured values of 0.377 " to 0.428 ". These measurements all indicate that the tanks have seen minimal degradation.

\subsection{DEGRADATION MECHANISMS}

The corrosion degradation of the tanks and drums containing the heavy water may occur by several mechanisms depending on the water chemistry and presence of crevices. In general, the majority of the drums and all the tanks contain fairly clean heavy water with concentrations of impurities at low levels. These mechanisms even if active may not be significant and affect the lifetime of the drums and tanks. The following section provides an evaluation of potential degradation mechanisms based on the known storage conditions of the tanks and drums.

Solution conductivity is a variable that affects all these corrosion mechanisms, which are electrochemical processes. The conductivity is a measure of the water quality. A lower conductivity or conversely a higher solution resistance leads to lower corrosion since the availability of aggressive species is lower and the flow of electrons more difficult. 
The wet storage of spent nuclear fuel at SRS provides an excellent example of the effect of conductivity on corrosion. As part of their Basin Management Program, water conductivity was lowered almost $200 \mu \mathrm{S} / \mathrm{cm}$ over a four year period [40]. Aggressive species were also lowered to approximately $200 \mathrm{ppb}$. During that time, no new initiation of pitting was observed on corrosion surveillance coupons that were placed in the basins. Additionally, laboratory testing in support of the basin program showed that for aluminum cladding alloys that conductivities less than $50 \mu \mathrm{S} / \mathrm{cm}$ were insufficient to cause pitting [41]

The specification for heavy water use in the reactors had a conductivity limit of $30 \mu \mathrm{S} / \mathrm{cm}$ [42]. This low conductivity requirement was a means to obtain low concentrations of impurities that could be absorb neutrons or cause corrosion of aluminum or stainless steel components. A total of 286 drums have conductivities $>30 \mu \mathrm{S} / \mathrm{cm}$ and 266 drums have conductivities $>50 \mu \mathrm{S} / \mathrm{cm}$.

\subsection{CREVICE CORROSION}

Crevice corrosion is a primary degradation mechanism for the drums as shown by the service history. During the manufacture of these drums, the closing seal welds for the bottom and the top form a crevice of varying size. This crevice size depends on the design and the fabrication quality. As discussed previously, changes have been made to the location of the weld as well as the configuration of the top, bottom and sidewall to minimize crevice size. Poor weld quality also may contribute crevices from porosity, inclusions, and overlaps.

Crevice corrosion may initiate in stainless steel by several mechanisms [43]. For 304 in neutral low chloride solutions, the dissolution of manganese sulfide inclusions is the probable cause of crevice corrosion. As the manganese sulfide dissolves, the solution becomes acidic with the generation of hydrogen ions in addition to manganese and thiosulfate ions [44]. As the $\mathrm{pH}$ drops, the thiosulfate breaks down and anodic dissolution of the stainless surface commences. The corrosion products especially chromium cause water hydrolysis, which leads to further acidification of the water and migration of chloride ions into the crevice. This increased aggressiveness leads to general breakdown of the passive oxide.

In a higher chloride solution, the passive film could breakdown due to changes in the electrochemical nature of the passive film. This level will be influenced by temperature, the opening and depth of the crevice as well as other constituents in the solution. Mathematical modeling of the crevice corrosion process has been developed and with experimental inputs has been used to define predicted resistances to crevice corrosion of stainless steels in chloridebearing waters [45]. For 304, exceptional resistance is obtained at levels near 200 ppm. Others have reported a safe chloride limit of $100 \mathrm{ppm}$ for 304 [44]. Crevice corrosion and pitting are affected similarly by these variables because the mechanisms are similar. The effect of the solution constituents and temperature are discussed in detail below for pitting corrosion.

As referred to above, crevice size is a factor that contributes to the probability or likelihood of crevice corrosion occurring. Mathematical modeling has shown that the deeper the crevice and the narrower the opening or gap the more likely crevice corrosion will be to occur. The crevice size also affects the ratio of the cathode area to the anode area. Simplistically, the anode area is 
the active corroding portion of the crevice where the dissolution or anodic reaction is occurring. The cathode is generally the area surrounding the crevice on the exterior. As this ratio increases or the cathode size increases, the probability of crevice corrosion increases as shown for stainless steels including 304 in Figure 7-1. The exposure was in flowing ambient temperature seawater for 30 days. The bold/crevice area ratio is the same as the cathode/anode surface area. However, the implication for the drums is still the same; crevice corrosion has a significant probability since the interior surface of the drum can be the cathode.

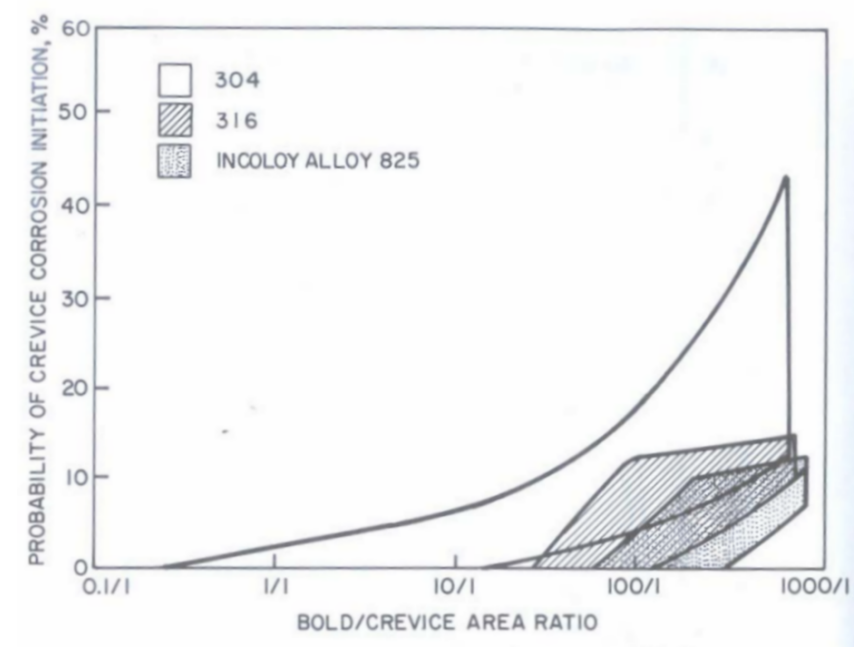

Figure 7-1 Probability of crevice corrosion initiation as a function bold/crevice area ratio [43]

\subsection{PITTING CORROSION}

A number of reported drum failures were associated with pitting in the sidewall, bottom or top. These failures were attributed to the presence of corrosive agents including chlorides and sulfates, which was a function of corrosion direction, i.e. outward from the interior or inward from the exterior. Material properties affect the pitting resistance in stainless steel. These properties include the presence of manganese sulfides, sensitization of the metal, surface condition and the effects of cold work [44]. The effects of cold work have been found to either increase or decrease pitting resistance but this effect is small.

The presence of manganese sulfides is probably the most important factor contributing to the pitting resistance since the sulfides are sites of pit initiation [43]. The sulfides dissolve, especially in chloride bearing solutions, at the corrosion potential of stainless steel. A small pit without a protective oxide and containing an acidic environment is left for the dissolution of the base metal and propagation of the pit. The effectiveness of a sulfide inclusion as pit initiators is dependent on its shape, size and chemistry.

Welding of the drums can lead to sensitization of the base metal, which is the formation of chromium carbides that result from a thermal transient into a critical temperature range. The carbide formation results in low-chromium areas of the base metal where the protective oxide does not form and pitting more easily initiates [43]. These sites are more favored than the 
manganese sulfides. For 304, the manganese sulfides in the weld metal redistribute and provide a superior pitting resistance than the base metal.

The surface condition of stainless steel can alter the pitting resistance [43]. Heat treatments, grinding and abrasive blasting tend to decrease the pitting resistance. Pickling and passivation are beneficial due to the removal of manganese sulfides, embedded iron particles and the outer oxide layer which can be depleted in chromium. As part of the procurement specification, the drums receive a passivation and rinse as the last step during fabrication. However, the drums are only washed out between uses which may leave surface corrosion products from previous exposures.

The pitting process is also affected by the environment including the temperature and water chemistry including aggressive species, oxygen and hydrogen ion $(\mathrm{pH})$ concentrations. In the case of the heavy water aggressive species include chloride, thiosulfate (from manganese sulfides), mercury, copper and permanganate. For stainless steel the susceptibility to pitting increases with chloride concentration. A measure of this susceptibility is the pitting potential. The pitting potential is an electrochemical measure at which pitting is found to initiate and propagate in a given solution. As the concentration of chloride increases the pitting potential decreases logarithmically and pitting becomes more likely. The effect of chloride and temperature for 304 is shown in Figure 7-2 [46]. At a given chloride concentration, the pitting potential decreases and pitting susceptibility increases with a rising temperature. These electrochemical changes are a manifestation of the change in the protective nature of the oxide film.

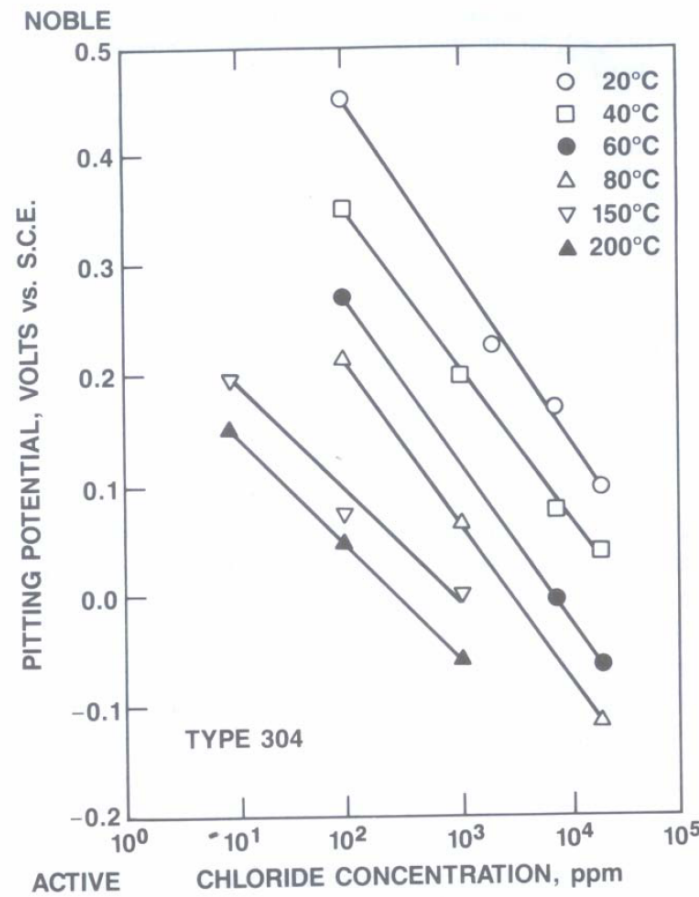

Figure 7-2 Effects of chloride concentration and temperature on the pitting potential of 304 stainless steel [46] 
A chloride concentration limit for pitting in the heavy water drums and tanks can not be absolute because of the complex chemistry but guidelines can be derived from available literature data. Figure 7-3 shows that for 304L pitting was unlikely for chloride concentrations less than 100 ppm [43]. The testing involved air-saturated solutions at $60^{\circ} \mathrm{C}$ with $\mathrm{pH}$ values from 2-8. $\mathrm{pH}$ adjustments were made with sulfuric acid. The test temperature of $60^{\circ} \mathrm{C}$ is far greater than expected storage conditions [47]. As shown in Figure 7-2, the pitting potential increases with decreasing temperature so the chloride limit would also increase with lower storage temperatures.

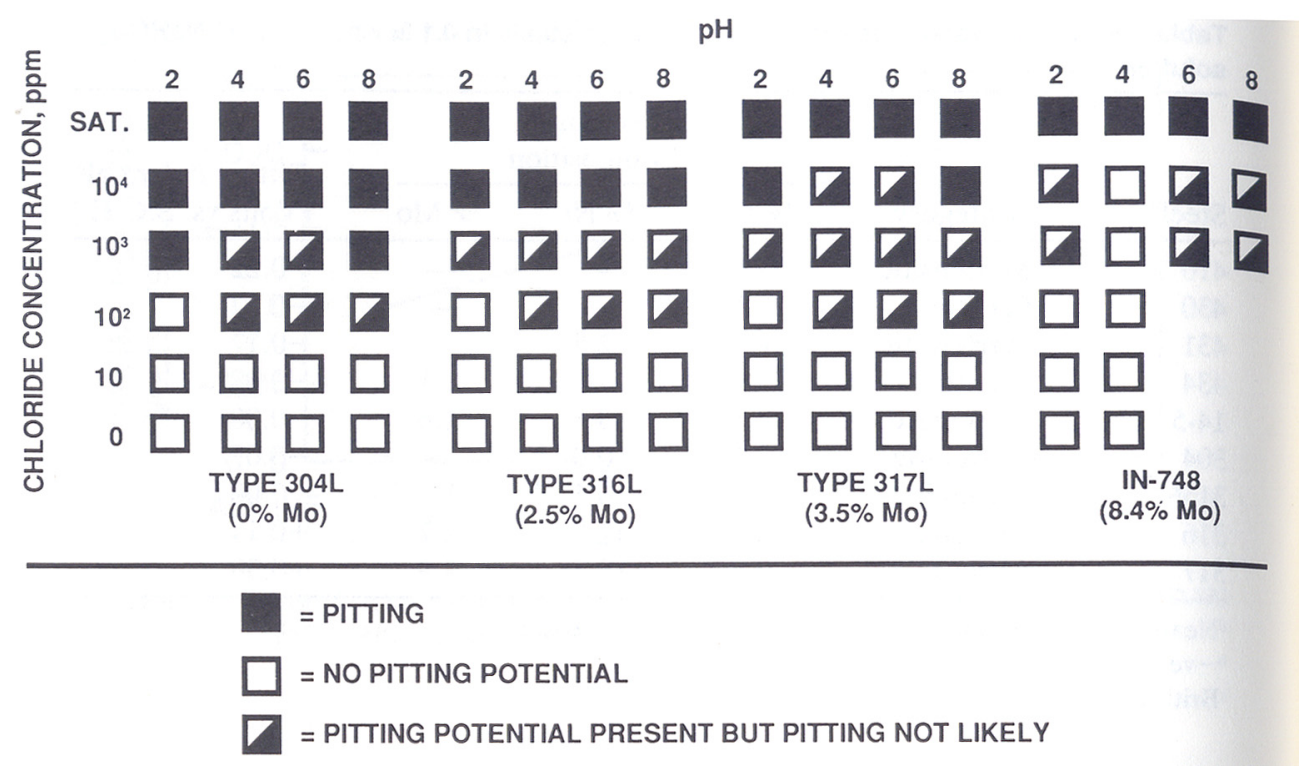

Figure 7-3 Pitting of nickel containing alloys as a function of chloride concentration and $\mathrm{pH}$ values in air saturated solutions at $60{ }^{\circ} \mathrm{C}$ [43]

Even in the absence of chloride, pitting can occur due to the dissolution of manganese sulfides as discussed above. This dissolution leads to a local acidification and the formation of thiosulfate ions. For 304, pitting readily occurs in a solution $(\mathrm{pH}=4.5)$ with $10 \mathrm{ppm}$ thiosulfate at a temperature of $50{ }^{\circ} \mathrm{C}$ as shown in Figure 7-4. 304 pitted at potentials even in the active range, i.e. less than $100 \mathrm{mV}$, which is well below the normal corrosion potential for stainless steel. .

The mercury, copper and permanganate ions all act as cathodic depolarizers, i.e. they accelerate the cathodic reaction for the corrosion process [43]. This acceleration results from either increase efficiency of cathodic areas or as an additional cathodic reaction. The increased efficiency results from metal ions that deposit on the stainless steel surface which have a smaller overpotential for the cathodic reaction, which is oxygen reduction at neutral and alkaline $\mathrm{pH}$ water or hydrogen reduction in acidic water. For mercury, the concentration must be greater than $0.5 \mathrm{ppm}$ to aggravate the corrosion due to the amalgamation of the stainless steel surface [48]. 


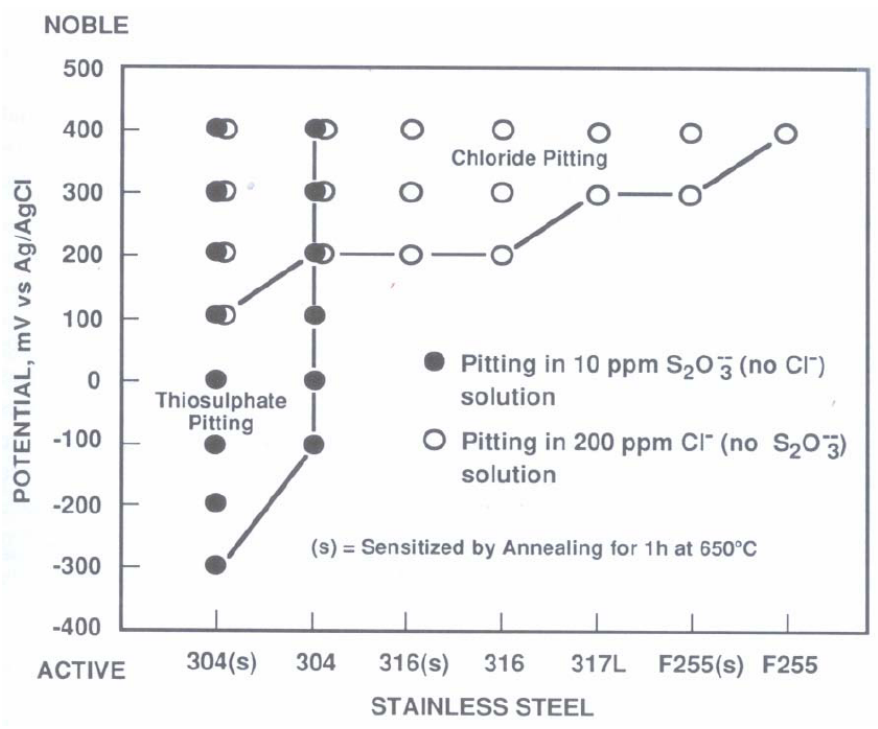

Figure 7-4 Pitting of stainless steels in chloride-containing and thiosulfate containing solutions at 24-hour potentiostatic tests [43]

\subsection{GALVANIC CORROSION}

The occurrence of galvanic corrosion is limited to the exterior of some drums. There are no dissimilar metal contacts on the can interior. On the exterior, the stainless steel body of the drum might be in contact with galvanized pallets or carbon steel strapping. Some drums were made with carbon steel roll hoops or robars. In water environments, stainless steel is generally more noble than carbon steel so the carbon steel corrodes preferentially. Stainless steel corrosion can be initiated from embedded steel particulate or possibly iron corrosion products.

To develop a couple between the stainless drum and the other dissimilar metal components requires moisture to accumulate. The drums are stored inside and thus not exposed to rainfall. Since the buildings are not temperature controlled, condensation on the drums or walls could provide some moisture although this has not been noted to be an issue.

Some of the carbon steel chimes and roll hoops have corroded with a visible layer of corrosion products, although this layer is generally superficial. This corrosion may have occurred when the drum was previously stored outside. The galvanized pallets appeared to be in good condition with no visible corrosion. Some of the drums had been banded with carbon steel strapping either previously or currently. In some cases, the strapping showed no corrosion so the drums have probably been stored inside since banding. Some drums showed corrosion product staining from previous carbon steel strapping that had been removed, but the drums had no significant corrosion of the sidewall. Whether the corrosion of the strapping occurred during inside or outside storage is unknown. The concern with corrosion of the carbon steel strapping is its loss of integrity which may impact safe handling and movement of the drums. 
SRNL-TR-2009-00195, REVISION 0

Although galvanic corrosion of the drums is unlikely to cause significant wall loss, monitoring of the building humidity levels may be a prudent measure to verify that at no time during inside storage are the drums susceptible to condensation and activation of galvanic couples.

\subsection{MICROBIOLOGICAL CORROSION}

Microorganisms are present in virtually all natural aqueous environments; however the presence of bacteria does not necessitate their involvement in the corrosion process. Specific bacteria have been identified that lead to localized corrosion of stainless steel. Bacteria include iron and manganese oxidizing bacteria and sulfate reducing bacteria. Bacteria attach to surfaces and develop biological films or colonies, which contain both aerobic and anaerobic bacteria, where bacteria can have synergistic relationships. Bacteria affect the corrosion process by changing the local environment including $\mathrm{pH}$, oxidizing power and concentration of aggressive species $\left(\mathrm{Cl}^{-}\right.$, $\mathrm{Fe}^{+3}$ ). Along with these environmental changes, the presence of a non-continuous film leads to the development of oxygen and chemical concentration cells. The oxygen depleted regions are where the protective oxide breaks down and initiates the localized corrosion.

For stainless steels, welds and heat-affected zones are a frequent location for microbiological influenced corrosion (MIC), which is manifested as pitting [43]. The pits have a characteristic morphology with a minute pinhole penetration with large subsurface cavities. On the surface there are deposits which are generally discrete mounds with colors distinctive to the type of bacteria, such as the red tubercles associated with iron-oxidizing bacteria (Gallionela). The pits are enriched with chromium and chloride. With chloride present, cracks can radiate from the pits depending on the surrounding stress field. The reasons that films or colonies develop are insufficient biocides and poor practices after hydrotesting including leaving standing impure water.

The bacteria growth and proliferation occurs over a broad range of conditions. Optimal conditions for bacteria associated with MIC are (parenthetic values show the range) for temperature, $15-45^{\circ} \mathrm{C}\left(0-99^{\circ} \mathrm{C}\right)$ and $\mathrm{pH}, 6-8(0-10.5)$. The energy sources also cover a broad range including oxygen, nitrate, carbon dioxide and sulfate. The storage of heavy water in drums at warm temperatures $\left(30-40^{\circ} \mathrm{C}\right)$ without biocides and some amount of chloride makes it favorable for the development of biofilms if bacteria associated with MIC are present.

Characterization of bacteria in the SRS heavy water has been conducted to a limited extent [49]. The toxicity of gadolinium on the growth of bacteria and algae was studied at SRS to assess the use of microorganisms as a means to purify the water. Six drums were evaluated over a range of $\mathrm{pH}(1.6-6.8)$, gadolinium concentration $(0.09-202500 \mathrm{mg} / \mathrm{L})$, conductivity $(1.4-84400$ $\mu \mathrm{mhos})$, and $\% \mathrm{D}_{2} \mathrm{O}(2.99-99.59)$. Bacteria were found present in all drums from a low number of $8.3 \times 10^{3}$ up to $1.3 \times 10^{6}$. The addition of a carbon source (glucose) to the heavy water sample stimulated bacterial growth. Their growth in heavy water was found to be slower than normal water, but the long-term effects of heavy water exposure are unknown. The effect of these bacteria on corrosion is not known since they were not characterized for typical bacteria associated with MIC. 
No drum failures have been associated with microbiologically influenced corrosion (MIC) although MIC was suspected in drums that were examined by digital radiography in the mid 1990s [50]. These indications, however, were not confirmed. At least one early failure displayed pit morphologies that are characteristic of MIC as shown in Figure 6-1. This failure was associated with fly ash accumulation during an external exposure. Since known occurrences of MIC are generally associated with welds, MIC in the heavy water drums are possible where many failures have been due to welds. Characterization of bacteria should be completed to determine if bacteria known to be associated with MIC are present.

\subsection{STRESS CORROSION CRACKING}

Stress corrosion cracking (SCC) is one of the failure modes found in the drums. For SCC to occur, three principal factors need to be present: a susceptible material, a stress, an aggressive environment. All three of these factors can occur for the drums, but are probably unlikely for the tanks.

The material of construction for both the tanks and drums is 304 so compositional differences, i.e. nickel and chromium concentrations, are not a consideration. The microstructure of 304, however, can significantly affect susceptibility, especially the presence of chromium carbides. Sensitization in the weld area results from heating in the temperature range $480-760{ }^{\circ} \mathrm{C}$ and slowly cooling, which allows chromium carbides to precipitate at the grain boundaries. The regions of chromium depletion that surround the carbides have oxides where corrosion can more easily initiate and under stress are likely areas for crack initiation. For 304 stainless steel, the threshold stress intensity factor for SCC susceptibility decreases as a result of sensitization. In the sensitized regions cracking generally propagates along the intergranular pathways, but in non-sensitized material transgranular cracking is predominant. The presence of manganese sulfides unlike the chromium carbides has no effect on stress corrosion cracking in austenitic stainless steels [43].

For the last shipment of drums received in 1995/6, the drums could be 304L in which the carbon concentration would be less than $0.03 \%$ carbon. This lower carbon reduces the susceptibility to sensitization and stress corrosion cracking.

One additional metallurgical factor that affects stress corrosion cracking in austenitic stainless steels is the amount of cold work [43]. The forming of a metal results in plastic deformation occurring in the metal which results in an increase in tensile and yield strength with a decrease in ductility. The cold work leads to a greater time to failure by SCC for a constant applied stress or a greater stress to obtain cracking in a similar time. The drum top and bottoms are formed pieces, so some degree of cold work has resulted. The effect on SCC resistance for the drums, however can not be quantified since there is a lack of information about the mechanical properties of the formed drums.

The occurrence of SCC is a function of chloride concentration. As chloride concentration increases, the time to failure increases. Figure 7-5 shows this effect for 304 stainless steels samples that were exposed at $100{ }^{\circ} \mathrm{C}$ under the concentration conditions of a Wick test where the salt solution is wicked to a heated surface allowing concentration of chlorides. In this test the 
chloride solution is brought to the stainless steel surface through a porous medium. For the chloride concentrations shown, all the samples failed eventually.

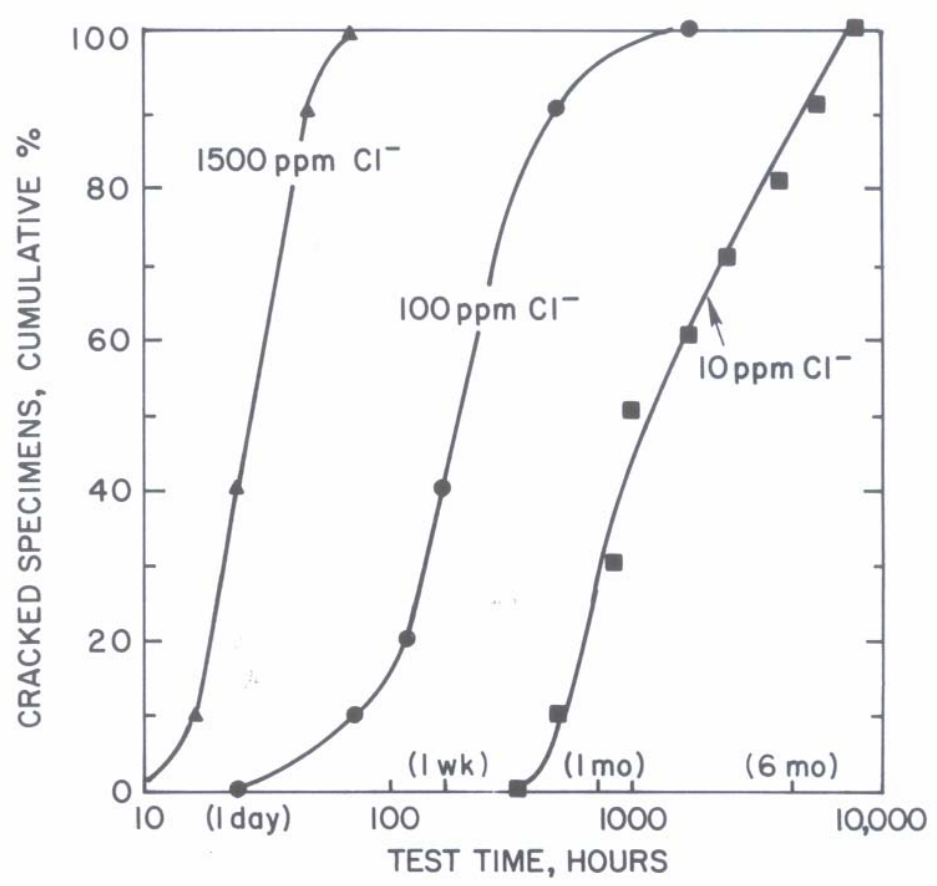

Figure 7-5 Effect of chloride concentration on the SCC susceptibility of 304 stainless steel exposed at $100{ }^{\circ} \mathrm{C}$ under the concentrating condition of the Wick tests [43]

The effects of metallic cations that are present in the heavy water have not been studied extensively. Mercury and copper have been shown to aid in cracking but at higher temperatures and concentrations. The hydrogen concentration, i.e. $\mathrm{pH}$, however, has a significant effect on cracking [43]. As the $\mathrm{pH}$ is lowered time to failure via $\mathrm{SCC}$ decreases while at higher $\mathrm{pH}$ the failure time increases. In testing with 304 stainless steels, cracking was found at neutral $\mathrm{pH}(6-8)$ with temperatures at $185-200^{\circ} \mathrm{F}\left(85-93{ }^{\circ} \mathrm{C}\right)$ and chloride levels as low a $5 \mathrm{ppm} \mathrm{Cl}$. In a study by Rideout at SRS, sensitized 304 samples were found to crack in a $10 \mathrm{ppm} \mathrm{Cl}^{-}$at $90^{\circ} \mathrm{C}$ with $\mathrm{pH}$ in the range of approximately 2.5 to 7 . At lower $\mathrm{pH}$ values cracking was not observed since the solution $\mathrm{pH}$ was adjusted with nitric acid and the sample passivated.

Temperature also has a significant effect on SCC. A temperature of $60^{\circ} \mathrm{C}$ was once thought to be a lower limit below which chloride stress corrosion cracking did not occur. Service failures over swimming pools and near marine environments have shown SCC can occur at room temperature [52]. Increasing temperature does lead to decreases in time to failure but also a transition from pitting to SCC. Figure 7-6 shows the results of a study with 304 in which the chloride concentration, $\mathrm{pH}$ and temperature were varied. These tests were performed in sodium chloride solutions with $\mathrm{pH}$ adjustments made with additions of either sodium hydroxide or hydrochloric acid. From these data, SCC was not observed at $100 \mathrm{ppm}$ in the temperature range of interest for heavy water storage $\left(<85^{\circ} \mathrm{F}\right)$. 


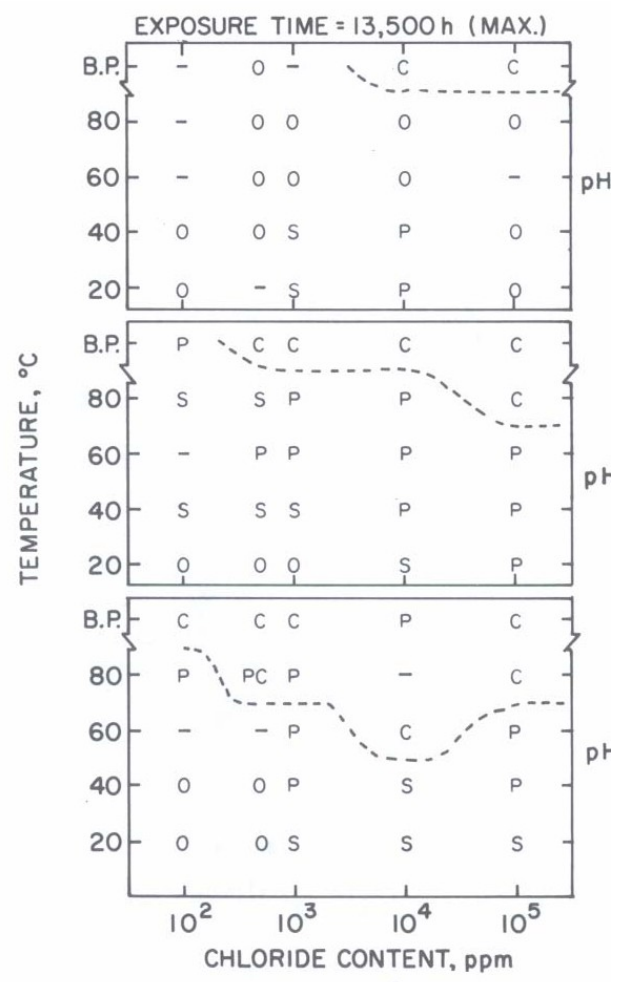

Figure 7-6 Effect of temperature, $\mathrm{pH}$ and chloride concentration on SCC susceptibility of 304 stainless steel in sodium chloride solutions $(\mathrm{C}=\mathrm{SCC}, \mathrm{P}=\mathrm{Pits}, \mathrm{S}=$ stains, $\mathrm{O}=$ no effect $)$ [52]

One final environmental factor that affects SCC is the presence of oxygen. Although not necessary for SCC depending on other conditions, the presence of oxygen can accelerate SCC. In the drums which are opened to the atmosphere some amount of oxygen is expected to be present, although this level will be relatively constant for drums that are not moved.

Some soluble species are known to be inhibitive against SCC. One particular species important for the drums is nitrate [43]. The $\mathrm{pH}$ of the heavy water was adjusted with nitric acid when the reactors were operating to minimize the corrosion of the aluminum clad fuel. Also some of the drums contain gadolinium which was used in the secondary safety system as a nuclear poison. The gadolinium was added as a nitrate salt. Nitrates are inhibitors to stainless steel. The effect of nitrates was previously shown by Rideout results in which SCC ceased below a $\mathrm{pH}$ of 2.5 when $\mathrm{pH}$ adjustments were made with nitric acid. This change in corrosion mechanism is associated with the protective nature of nitrates. An estimate was made for the nitrate concentration necessary to inhibit heavy water drums with $250 \mathrm{ppm}$ [53]. The amount necessary was 1000 ppm, which is a quantity that has been measured previously in heavy water drums [49]. In future heavy water analysis, nitrate concentrations should be recorded especially for high chloride-containing water. These data would provide a measure of the water inhibition.

Defining a minimum chloride concentration below which SCC will not occur is difficult because of the effects of metallic cations, $\mathrm{pH}$, oxygen concentration, and other reducible or adsorbed species. Some general minimum concentrations have been defined by API depending on the 
application. For example, API 650 which covers storage tanks specifies a maximum chloride concentration of $200 \mathrm{ppm}$ for temperatures less than $40{ }^{\circ} \mathrm{C}$ and $100 \mathrm{ppm}$ for temperatures between 40 and $65{ }^{\circ} \mathrm{C}$, whereas API 651 specifies a maximum of $50 \mathrm{ppm}$ for hydrotesting water $[54,55]$. The SRS engineering standard, \#05952 "Required Practices to Minimize Chloride Induced Stress Corrosion Cracking of Type 300 Series Austenitic Stainless Steel”, specifies a maximum chloride level of $250 \mathrm{ppm}$ at $740{ }^{\circ} \mathrm{C}$ [56]. For the heavy water drums and tanks, a suggested guideline is a maximum chloride concentration of $100 \mathrm{ppm}$ based on the literature data presented in this report since the storage temperatures and concentrations of other impurities are low.

\subsection{CONCLUSIONS AND RECOMMENDATIONS}

The safe storage of heavy water in 55-gallon drums and large-capacity tanks has been on going at the Savannah River Site over the last 50 years. The drums have had an average failure due to leakage of one drum every two years, with the leaks being small; the tanks have had no known leaks to date. A review of the service history and potential corrosion mechanisms shows that the drums are most susceptible to crevice corrosion, pitting and stress corrosion cracking, especially with impure water. The high purity water should preclude an incidence of active corrosion in non-crevice regions; however crevice regions may continue to be vulnerable to corrosion attack.

An inspection and monitoring plan is being prepared which will assure the continued safe storage of heavy water in the existing drums and tanks and support avoidance of any future leakage failures. The following findings from this degradation report will be used to develop the plan, including the basis for the inspection locations and frequencies.

$\underline{\text { Recommended Actions }}$

- Analysis of tank chemistries are suggested to verify there has been no significant change.

- The monitoring of the moisture in the drum storage is suggested to fully characterize storage conditions.

- A bacterial profile should be assessed to determine if known species for MIC are present.

- Corroded carbon steel chimes are not indicative of the state of the primary boundary, but their integrity should be verified for safe handling.

$\underline{\text { Inspection Plan Inputs }}$

- Heavy water storage drums are susceptible to crevice, pitting and stress corrosion if water contains chlorides greater than $100 \mathrm{ppm}$ for normal storage temperatures $\left(>85^{\circ} \mathrm{F}\right)$.

- The weld of the bottom to sidewall produced variable size crevices due to drum design and weld quality.

- Weld quality is variable for the drums with poor weld quality leading to leakage such as shrinkage cracks, lack of penetration and excess burn-through.

- Heavy water quality is an indicator of current probability of corrosion but does not indicate damage suffered by the drum from previous stored heavy water. 


\subsection{REFERENCES}

1. "Specification for DOT/UN 1A1 55 Gallon Stainless Steel Drums," G-SPP-K-00005, Rev. 3, February 22, 1995

2. "Specification for DOT/UN 1A1 55 Gallon Stainless Steel Drums," G-SPP-K-00005, Rev. 4, April 16, 1996

3. "SRP Engineering Standard and Specification: 55-Gallon Drum for Transporting LSA Heavy Water,” EED 870373, Rev. 6, August 25, 1987

4. "SRP Engineering Standard and Specification: 55-Gallon SS Drum," DPSOL-208-1, Part II, Rev. 2, April 5, 1976

5. E. J. Majzlik, "Evaluation of Moderator Storage Drums with Concave Heads," SRT-MTS955109, May 12, 1995.

6. N. K. Gupta, "Structural Evaluation of Concave Moderator Drum Heads," M-CLC-D00069, Rev. 0, April 19, 1995

7. “Horizontal Storage Tank, 12'-0” O.D. $\times$ 12'-8-1/2' Long $\times 1 / 2$ ” Thick,” Drawing 112904

8. “Horizontal Storage Tank, 12'-0” O.D. $\times$ 43'-0' Long $\times 1 / 2$ ” Thick,” Drawing 112903

9. “Horizontal Storage Tank, 12'-0” O.D. $\times$ 52'-0' Long $\times 1 / 2$ ” Thick,” Drawing 112975

10. “Horizontal Storage Tank, 10’-0” O.D. $\times 12$ '-0' Long $\times 3 / 8 ”$ Thick,” Drawing 118021

11. EXCEL Spreadsheet, "Moderator Tanks Sample Results," May 2, 2007

12. EXCEL Spreadsheet, "HW Spreadsheet Users Group,” February 11, 2009

13. "Use of Drum Records for Moderator Accountability," SOP-MODS-006-L, Rev. 1, December 13, 2005

14. D. W. Tharin, "Failed $\mathrm{D}_{2} \mathrm{O}$ Drums," DPSPU-76-272-344, July 27, 1976

15. J. R. Harpring “Leaking Moderator Shipping Drums,” HW-E17-11, April 25, 1973

16. W. S. Ehrhart, "Failed Moderator Storage Drums," EED 421-D Metallurgical Report, November 5, 1982

17. S. P. Nootens, "Carbon Steel Heavy Water Drum Chime Bands," EPD-QCM-890205, July 28, 1989 
18. D. M. Cato, "Drum Investigation Committee Final Report,” WSRC-TR-94-0184, April, 7, 1994

19. E. M. Vessel and D. Z. Nelson, “Failure Analysis of Heavy Water Drum," SRT-MTS935181, November 29, 1993

20. Personal communications with and files of D. Z. Nelson, May, 2009

21. P. E. Vormelker, "Chemical Analysis of Solid and Liquid Residue Leaking from Drum No. 12456," SRNL-MTS-2005-30001, January 12, 2005

22. J. W. Hyres, “Heavy Water Shipping Drums,” EED 870338, July 10, 1987

23. D. Z. Nelson, "Failure Analysis of Redesigned Moderator Storage Drum," SRT-MTS-963033, January 24, 1996

24. B. D. Howard, "EF\&RFS Moderator Drum Procurement Guidelines," SRT-SRS-96-0119, April 15, 1996

25. H. A. Taylor, “Leaking Moderator Shipping Drums,” HW-E17-11, January 30, 1967

26. "Specification for DOT/UN 1A1 55 Gallon Stainless Steel Drums," G-SPP-K-00005, Rev. 5, October 5, 1997

27. C. E. Varner and J. A. Roach, "Evaluation of WSRC Drum Procurement Requirements and Recommended Path Forward," WSRC-TR-96-0252, Rev. 0, September 16, 1996

28. Procurement Data Sheet, "55-Gallon DOT UN1A1 Stainless Steel Drums," M-DS-L00006, September 2005.

29. Moderator Storage Area Inspection, SOP-MODS-010-L, Rev. 2, July 16, 2007

30. Code of Federal Regulation, Title 49, Part 178, Subpart L, 2009

31. “Transfer of Moderator Between Containers," SOP-MODS-007-L, Rev. 1, June 5, 2007

32. S. D. Fulbright and R. B. Groon, "Moderator Shipping Drums," EED 400-D Metallurgical Report, HW-G20-3, May 19, 1978

33. E. K. Opperman, "Transmittal of Test Report IP-2 (Drum) Packaging,” SRL-PTG-92-0027, April 22, 1992

34. J. I. Mickalonis, "A Corrosion Study for Heavy Water Storage Drums," SRT-MTS-962056, January 20, 1997

35. “Shipping Moderator Drums,” SOP-MODS-004-L, Rev. 4, October 18, 2008 
36. Ultrasonic Thickness Reports $2001-2008$.

37. P. Smock, "Nondestructive Examination Condition Report," SRNL-MTS-2004-60575, October 19, 2004

38. P. Smock, "Nondestructive Examination Condition Report," SRNL-MTS-200560152, March 15, 2005

39. R. J. Sunderland, "Nondestructive Examination Condition Report," SRNL-MTS-200560133, October 9, 2008

40. J. P. Howell, "Corrosion of Aluminum-Clad Spent Fuel in Reactor Basin Water Storage," Corrosion95, Paper \# 429, NACE International, 1995

41. G. T. Chandler et al, "Evaluation of Water Chemistry on the Pitting Susceptibility of Aluminum," Corrosion97, Paper \# 104, NACE International 1997

42. E. W. Bauman, "Corrosion/Chemistry in Long-Term Drum Storage of Heavy Water," SRT-ADS-93-0382, August 25, 1993

43. A. J. Sedriks, Corrosion of Stainless Steel, $2^{\text {nd }}$ Ed, John Wiley \& Sons Inc, 1996

44. S. E. Lott and R. C. Alkire, "The Role of Inclusions on Initiation of Crevice Corrosion of Stainless Steel," J Electrochem Soc, Vol 136 (4), pp973-979, 1989

45. J. W. Oldfield, International Materials Review," Vol 32 (3), pp 153-170, 1987

46. J-H Wang et al, "Effects of Chloride Concentration and Temperature on Pitting of AISI 304 Stainless Steel, Corrosion, Vol 44 (10, pp 732-737, 1988

47. Personal communications with W. E. Petty, 2009

48. H. L. Martin, "Rework Unit and Purification Facilities Technical Standard Maximum Allowable Mercury Concentration,” EFR-ENG-960053, September 15, 1996.

49. E. W. Wilde, Toxicity of Gadolinium to Some Aquatic Microbes, Bull Environ Contam Toxicol, Vol 68, pp 420-427, 2002

50. Digital Radiography Data Analysis Sheets, August 1994

51. T. Prosek et al, "Low Temperature SCC of Stainless Steels in the Atmosphere in the Presence of Chloride Deposits," Corrosion, Vol 65 (2), pp 105-117, 2009 
52. J. E. Truman, "Influence of Chloride Content, $\mathrm{pH}$, and Temperature of Test Solution on the Occurrence of Stress Corrosion Cracking with Austenitic Stainless Steel," Corr Sci, Vol 17, pp 737, 1977

53. J. I. Mickalonis, "Corrosion Inhibition of Moderator Stainless Steel Storage Drums by pH Adjustment," SRNL-MTS-2004-50030, December 16, 2004

54. API Standard 650, "Welded Tanks for Oil Storage," Eleventh Edition, June, 2007

55. API Recommended Practice 651, "Cathodic Protection of Aboveground Petroleum Storage Tanks," Third Edition, January, 2007

56. "Required Practices to Minimize Chloride Induced Stress Corrosion Cracking of Type 300 Series Austenitic Stainless Steel," \#05952, Revision 5, May 26, 2009, SRS Engineering Standards Manual, WSRC-TM-95-1 
APPENDIX A. Heavy Water Drum Failure Listing

\begin{tabular}{|l|c|c|l|l|}
\hline $\begin{array}{l}\text { Drum } \\
\text { Number }\end{array}$ & $\begin{array}{c}\text { Fabrication } \\
\text { Date }\end{array}$ & $\begin{array}{c}\text { Failure } \\
\text { Date }\end{array}$ & Failure Location & Cause of Failure \\
\hline 2961 & 1956 & 1969 & Bottom & Internal pitting \\
\hline 12026 & 1969 & 1970 & $\begin{array}{l}\text { Sidewall above } \\
\text { weld }\end{array}$ & Internal pitting \\
\hline 14366 & 1970 & 1972 & Bottom chime & Weld defect \\
\hline 6071 & 1956 & 1972 & $\begin{array}{l}\text { Bottom chime } \\
\text { weld }\end{array}$ & Weld defect \\
\hline 6050 & 1956 & 1972 & Unclear & Pitting \\
\hline 6077 & 1956 & 1973 & Bottom chime & Weld defect \\
& 1970 & 1975 & External bottom & Fly ash pit \\
\hline 14427 & 1970 & 1976 & External bottom & Fly ash pit \\
\hline 14536 & 1969 & 1976 & External bottom & Fly ash or standing water \\
pit
\end{tabular}

* Drum was not available for metallographic analysis; based on brief visual evaluation. 


\section{DISTRIBUTION}

Spent Fuel Project

R. W. Deible, Jr.

J. C. Guy

A. N. Holloway

D. L. Melvin

W. E. Petty

R. R. Reichel

D. B. Rose

T. J. Spieker

$\underline{\text { Savannah River National Laboratory }}$

G. T. Chandler

N. C. Iyer

J. I. Mickalonis

R. L. Sindelar

P. E. Vormelker

K. E. Zeigler 